\title{
Yield and quality of densely cultivated onion cultivars as function of nitrogen fertilization
}

\author{
Francisco das C. Gonçalves ${ }^{1}$, Leilson C. Grangeiro ${ }^{1}$, Valdivia de F. L. de Sousa ${ }^{1}$, Jandeilson P. dos Santos ${ }^{1}$, \\ Francisco I. de Souza ${ }^{1} \&$ Luiz R. R. da Silva ${ }^{1}$
}

\begin{abstract}
${ }^{1}$ Universidade Federal Rural do Semi-Árido/Centro de Ciências Agrárias/Departamento de Ciências Agronômica e Florestal, Mossoró, RN, Brasil. E-mail: francisco.goncalves@ufersa.edu.br (Corresponding author) - ORCID: 0000-0002-0730-9647; leilson@ufersa.edu.br - ORCID: 0000-0002-4613-3605; valdivia_sousa@hotmail.com - ORCID: 0000-0002-5377-6844; jandeilsonpereira@gmail.com - ORCID: 0000-0003-3708-2540; franciscoirael@hotmail.com ORCID: 0000-0002-2795-3632; luizricardo_5@hotmail.com - ORCID: 0000-0002-3346-478X
\end{abstract}

\begin{abstract}
Nitrogen exerts a marked influence on the yield and quality of the onion. The present work was developed from June to October 2016, aiming to evaluate the yield and quality of two cultivars of onion under a system densified as a function of nitrogen doses in Mossoró, RN, Brazil. A randomized block design was used in a $2 \times 7$ factorial scheme, with four repetitions, corresponding to two cultivars (IPA 11 and Rio das Antas) and seven nitrogen doses (0, 45, 90, 135, 180, 225 and $270 \mathrm{~kg} \mathrm{ha}^{-1}$ of N), provided by fertigation, with four repetitions. The dose of $92 \mathrm{~kg} \mathrm{ha}^{-1}$ of $\mathrm{N}$ provides the highest total and marketable yields of bulbs. Nitrogen fertilization increases the concentrations of $\mathrm{N}$, chlorophyll $\mathrm{a}, \mathrm{b}$ and total in the leaves of the onion, as well as the percentage of bulbs of classes 3 and 4 and the pungency, reducing the percentage of bulbs of class 2 and non-commercial. The doses of 108 and $82 \mathrm{~kg} \mathrm{ha}^{-1}$ of $\mathrm{N}$ provide the highest rates of return for 'IPA 11 ' (R\$2.07) and 'Rio das Antas' (R\$2.41), respectively.
\end{abstract}

Key words: Allium cepa, classification of bulbs, plant nutrition, economic indicators

\section{Produtividade e qualidade de cultivares de cebola adensadas em função da adubação nitrogenada}

RESUMO: O nitrogênio exerce influência marcante no rendimento e qualidade da cebola. O presente trabalho foi desenvolvido no período de junho a outubro de 2016, tendo como objetivo avaliar a produtividade e qualidade de duas cultivares de cebola sob sistema adensado em função de doses de nitrogênio em Mossoró, RN. Empregou-se o delineamento em blocos casualizados, no esquema fatorial $2 \times 7$, correspondendo às cultivares IPA 11 e Rio das Antas e sete doses de nitrogênio $\left(0,45,90,135,180,225\right.$ e $270 \mathrm{~kg} \mathrm{ha}^{-1} \mathrm{de}^{-1}$ $\mathrm{N}$ ), fornecidas via fertigação, com quatro repetições. A dose de $92 \mathrm{~kg} \mathrm{ha}^{-1}$ de $\mathrm{N}$ proporcionou as maiores produtividades total e comercial de bulbos. A adubação nitrogenada aumentou o teor de $\mathrm{N}$, clorofilas a, b e total nas folhas da cebola, bem como os percentuais de bulbos das classes 3 e 4 e a pungência, reduzindo os percentuais de bulbos da classe 2 e não comerciais. As doses de 108 e $82 \mathrm{~kg} \mathrm{ha}^{-1}$ de $\mathrm{N}$ proporcionaram as máximas taxas de retorno para 'IPA 11' $(\mathrm{R} \$ 2,07)$ e 'Rio das Antas' (R\$2,41), respectivamente.

Palavras-chave: Allium cepa, classificação de bulbos, nutrição de plantas, indicadores econômicos 


\section{INTRODUCTION}

Onion is cultivated in all regions of Brazil, with more than 58,000 ha planted in 2016, resulting in a production of $1,657,441 \mathrm{t}$ and an estimated income exceeding 1.85 billion reais (IBGE, 2017).

Despite recent advances, onion yield in the Northeast region is only $28,954 \mathrm{~kg} \mathrm{ha}^{-1}$, much lower than the averages obtained in the Southeast and Midwest regions, 44,332 and $46,354 \mathrm{~kg} \mathrm{ha}^{-1}$, respectively (IBGE, 2017). Such low yield in the Northeast region is related to the low technological level adopted by most onion producers, as well as to the quantities and forms of the nutrients applied.

The official recommendations of nitrogen fertilization for onion have varied among Brazilian states and consider basically a plant population of, at most, 500,000 plants per hectare and conventional application. In the São Paulo state, Brazil, nitrogen recommendation has varied from 80 to $120 \mathrm{~kg} \mathrm{ha}^{-1}$ in the seedling transplanting system and from 80 to $160 \mathrm{~kg} \mathrm{ha}^{-1}$ in the no-tillage system. For Minas Gerais state, Brazil, the recommendation is $120 \mathrm{~kg} \mathrm{ha}^{-1}$, whereas for Pernambuco state, Brazil, it is $150 \mathrm{~kg} \mathrm{ha}^{-1}$ (Factor et al., 2018).

This study aimed to evaluate the yield and quality of two onion cultivars under a dense cultivation system as a function of $\mathrm{N}$ doses in Mossoró, RN, Brazil.

\section{Material ANd Methods}

The experiment was carried out in the period from June to October 2016, at the Rafael Fernandes Experimental Farm of UFERSA, located in the rural area of the municipality of Mossoró (5 3' 37' S, 37² 23' 50” W and altitude of $72 \mathrm{~m}$ ). Along the experimental period, the average temperature was $27.2^{\circ} \mathrm{C}$ and the average relative air humidity was $64.5 \%$.

The soil was classified as Ultisol. Soil analysis at depth from 0 to $0.20 \mathrm{~m}$ revealed $\mathrm{pH}$ in $\mathrm{H}_{2} \mathrm{O}$ of 4.8 ; EC of $0.02 \mathrm{dS} \mathrm{m}^{-1}$; $0.8 \mathrm{mg} \mathrm{dm}^{-3}$ of $\mathrm{P}_{\text {Melich-1 }} ; 22.5 \mathrm{mg} \mathrm{dm}^{-3}$ of $\mathrm{K}$; concentrations of $\mathrm{Ca}, \mathrm{Mg}, \mathrm{H}+\mathrm{Al}$ and effective CEC were $0.4,0.2,1.49$ and $2.35 \mathrm{cmol}_{\mathrm{c}} \mathrm{dm}^{-3}$, respectively. The concentrations of sand, silt and clay were 900, 20 and $80 \mathrm{~g} \mathrm{~kg}^{-1}$, respectively.

A randomized blocks design was used in a $2 \times 7$ factorial scheme, corresponding to the cultivars Rio das Antas and IPA 11 and seven nitrogen $(\mathrm{N})$ doses $(0,45,90,135,180,225$ and $270 \mathrm{~kg} \mathrm{ha}^{-1}$ of N), with four repetitions, via fertigation. Each plot consisted of $3.0 \mathrm{~m}$ of bed with width of $1.0 \mathrm{~m}$, containing eight rows of plants, spaced by $0.10 \times 0.06 \mathrm{~m}$. The six central rows were considered as usable area, disregarding two plants on each end.

Irrigation was applied using a drip system, with four tubes per bed, spaced by $0.20 \mathrm{~m}$, and drippers with average flow rate of $1.5 \mathrm{~L} \mathrm{~h}^{-1}$, positioned $0.30 \mathrm{~m}$ apart. Irrigations were performed daily and the water depths were determined based on crop evapotranspiration (Allen et al., 1998), applying a total depth of $888.3 \mathrm{~mm} \mathrm{ha}^{-1}$.

The water used in irrigation came from a deep tubular well, from the Arenito Açu aquifer, with the following characteristics: $\mathrm{pH} 7.1 ; \mathrm{EC}=0.61 \mathrm{dS} \mathrm{m}^{-1} ; 0.65,1.73,2.50,1.90$, 1.60, 0.0 and $4.00 \mathrm{mmol}_{\mathrm{c}} \mathrm{L}^{-1}$ of $\mathrm{K}^{+}, \mathrm{Na}^{+}, \mathrm{Ca}^{+2}, \mathrm{Mg}^{+2}, \mathrm{Cl}^{-}, \mathrm{CO}_{3}^{-2}$ and $\mathrm{HCO}_{3}^{-}$, respectively, and SAR of $1.2\left(\mathrm{mmol} \mathrm{L}^{-1}\right)^{0.5}$.
Fertilization at planting consisted of $300 \mathrm{~kg} \mathrm{ha}^{-1}$ of $\mathrm{P}_{2} \mathrm{O}_{5}$ (Factor et al., 2018) in the form of superphosphate, $1.0 \mathrm{~kg}$ $\mathrm{ha}^{-1}$ of boron and $3.0 \mathrm{~kg} \mathrm{ha}^{-1}$ of zinc in the forms of boric acid and zinc sulfate, respectively. Topdressing fertilization was performed weekly through fertigation, split into nine applications, beginning at 20 days after sowing (DAS) and ending at 75 DAS, supplying $277.2 \mathrm{~kg} \mathrm{ha}^{-1}$ of $\mathrm{K}_{2} \mathrm{O}$ and 13.1 $\mathrm{kg} \mathrm{ha}^{-1}$ of $\mathrm{Mg}$, while $\mathrm{N}$ followed the doses of each treatment. The fertilizers used were urea, potassium nitrate, potassium chloride and magnesium sulfate.

Thinning was performed at 19 DAS, when the plants had two true leaves and only manual weeding was performed.

At 96 DAS, when, on average, $70 \%$ of the plants were lodged, irrigation was suspended and the curing process began. Twenty eight days after irrigation suspension, plants were harvested and cleaned.

The following variables were evaluated: $\mathrm{N}$ concentration in the diagnostic leaf $\left(\mathrm{g} \mathrm{kg}^{-1}\right)$, by the Kjeldahl method; concentrations of chlorophylls $\mathrm{a}, \mathrm{b}$ and total $\left(\mathrm{mg} \mathrm{g}^{-1}\right)$, by the method proposed by Scopel et al. (2011); total yield of bulbs $\left(\mathrm{t} \mathrm{ha}^{-1}\right)$, as the sum of marketable and non-marketable yields; marketable yield of bulbs $\left(\mathrm{t} \mathrm{ha}^{-1}\right)$, determined by the total weight of bulbs with diameter $>35 \mathrm{~mm}$, with no defects; classification of bulbs, according to the standards of the Ministry of Agriculture, Livestock and Food Supply (Brasil, 1995); percentage of nonmarketable bulbs (\%), considering those in Class $1(<35 \mathrm{~mm})$, double and defective bulbs; total soluble solids ( ${ }^{\circ}$ Brix); titratable acidity (meq $\left.\mathrm{H}_{3} \mathrm{O}^{+} 100 \mathrm{~g}^{-1}\right)$; soluble solids/titratable acidity ratio; and piruvic acid (pungency) ( $\mu \mathrm{mol} \mathrm{g} \mathrm{g}^{-1}$ ), according to Melo et al. (2012). The following economic indicators were determined: gross revenue (GR), calculated considering the estimated marketable production (MP) and the average price of the onion per kilogram paid in the region ( $R$ \$ 1.25) at harvest time; net revenue (NR), calculated as the difference between GR and production costs (PC) with inputs, considering the unit of $\mathrm{N}$ with price of $\mathrm{R} \$ 8.92 \mathrm{~kg}^{-1}, 4.0 \mathrm{~kg}$ of seeds $\mathrm{ha}^{-1}$ for 'IPA 11' and 1.1 million seeds for 'Rio das Antas' at costs of $\mathrm{R} \$ 197.93$ per 500 -g pack and R\$ 540.00 per 100,000-seed pack, respectively, and the remaining inputs were common to both treatments. The return rate (RR) was obtained by the relationship between GR and PC; profitability index (PI) was calculated by the relationship between net revenue (NR) and gross revenue (GR), expressed in percentage; break-even point (BEP) resulted from the relationship between PC and the average bulb price and safety margin (SM), obtained by the relationship between the difference of PC and GR, divided by GR.

The data were subjected to analysis of variance and, when there was a significant effect for the qualitative factor, the means were compared by $\mathrm{F}$ test at $\mathrm{p} \leq 0.05$, while regression analysis was carried out for the quantitative factor, using the program Sisvar version 5.6 (Ferreira, 2011), except for total and marketable yields, which were analyzed using the program SAEG (UFV, 1997).

\section{Results ANd Discussion}

The interaction between cultivars and $\mathrm{N}$ doses was significant for the percentages of onion bulbs in Classes 2, 3 
and 4, titratable acidity (TA) and pungency (PUNG). Apart from nitrogen concentration in the diagnostic leaf (NDL), chlorophylls a, b and total, all evaluated traits were influenced by the cultivars, whereas for the doses there was no significant effect on soluble solids (SS), titratable acidity (TA) and soluble solids/titratable acidity ratio (SS/TA) (Table 1 ).

Leaf $\mathrm{N}$ concentration increased linearly, as a function of the $\mathrm{N}$ doses, with an estimated maximum of $28.37 \mathrm{~g} \mathrm{~kg}^{-1}$ (Figure 1A). This result corroborates those obtained by Menezes Júnior \& Kurtz (2016).

The $\mathrm{N}$ concentration considered adequate by Trani et al. (2014) for onion (25 to $40 \mathrm{~g} \mathrm{~kg}^{-1}$ ) was observed in the present study, from the $\mathrm{N}$ dose of $135 \mathrm{~kg} \mathrm{ha}^{-1}$. In the treatment without $\mathrm{N}$ application, there were characteristic symptoms of $\mathrm{N}$ deficiency, such as small plants with yellowed leaves and bulbs of reduced size.

The mean concentrations of chlorophyll a fitted to a quadratic model, with maximum value of $0.21 \mathrm{mg} \mathrm{g}^{-1}$, at the $\mathrm{N}$ dose of $191.6 \mathrm{~kg} \mathrm{ha}^{-1}$ (Figure 1B). The mean concentrations of chlorophyll $\mathrm{b}$ and total chlorophyll did not fit to any regression model, with minimum value observed in the treatment without $\mathrm{N}$ and the maximum value was observed at the $\mathrm{N}$ dose of $225 \mathrm{~kg} \mathrm{ha}^{-1}$.

Excess of $\mathrm{N}$ leads to the increase of reactive oxygen species $\left(\mathrm{O}_{2}^{-}\right.$and $\left.\mathrm{H}_{2} \mathrm{O}_{2}\right)$, which may damage the photosynthetic apparatus and catalyze protein degradation due to the oxidative modification and increased proteolytic activity, causing inhibition of chlorophyll synthesis and/or degradation (Gao et al., 2012).

The total (TY) and marketable (MY) yields of onion bulbs as a function of $\mathrm{N}$ doses fitted to plateau-linear regression models. The $\mathrm{N}$ dose which maximized both TY $\left(71.21 \mathrm{t} \mathrm{ha}^{-1}\right)$ and MY (67.35 $\mathrm{t} \mathrm{ha}^{-1}$ ) was $92.0 \mathrm{~kg} \mathrm{ha}^{-1}$ (Figure 1C).

These results are consistent with those obtained by Rodrigues et al. (2018), who observed that TY and MY fitted to the plateau-linear model, and the $\mathrm{N}$ doses of 67.5 and 116.2 $\mathrm{kg} \mathrm{ha}^{-1}$ maximized TY in the periods $1\left(28.93 \mathrm{t} \mathrm{ha}^{-1}\right)$ and 2 $\left(51.97 \mathrm{t} \mathrm{ha}^{-1}\right)$, respectively, whereas the $\mathrm{N}$ doses of 77.7 and $113.66 \mathrm{~kg} \mathrm{ha}^{-1}$ were responsible for the maximum MY in these same periods.

Excessive $\mathrm{N}$ supply may lead to increased respiration and, therefore, lower photosynthetic yield (Isla et al., 2016), which would explain the stabilization in onion yield.

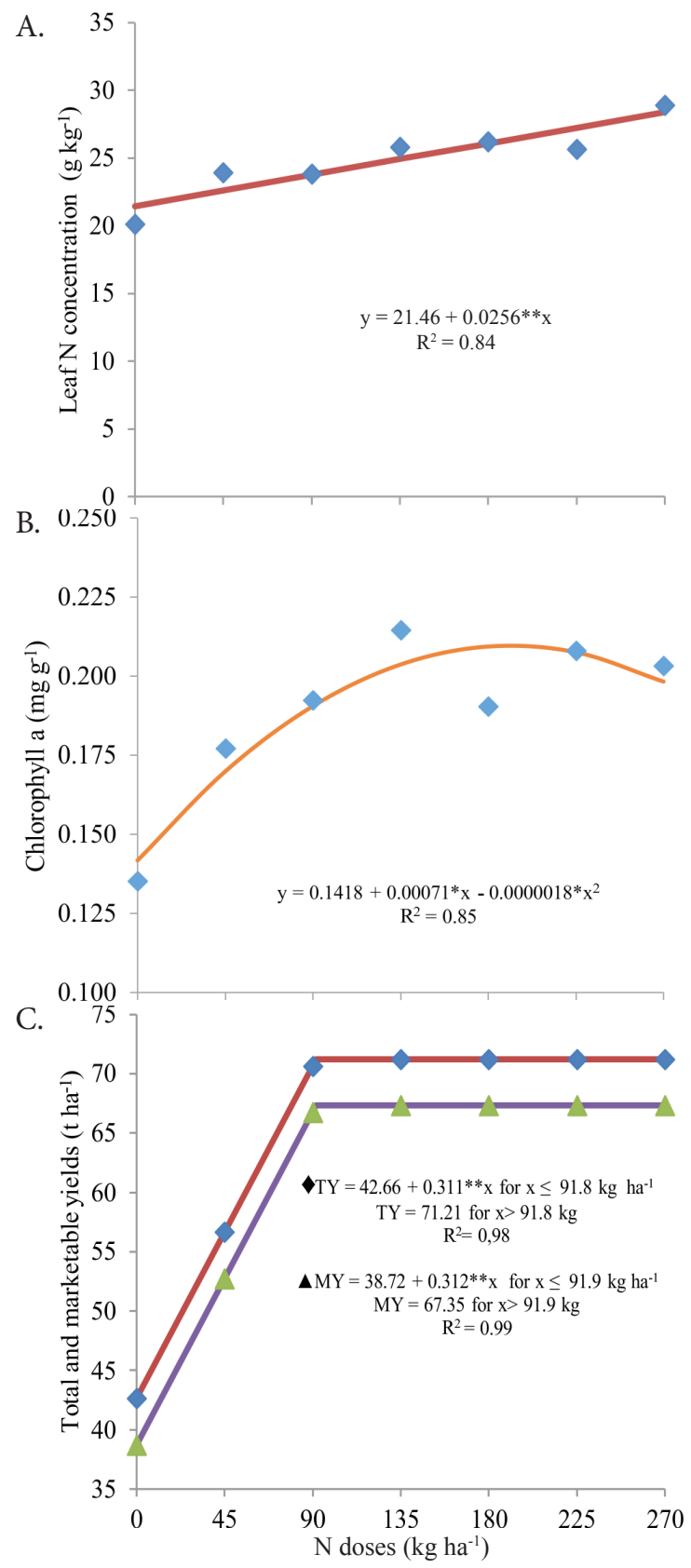

Figure 1. N concentration in the diagnostic leaf (A), chlorophyll a concentration (B), total and marketable yields of onion bulbs (C), as a function of $\mathrm{N}$ doses

Table 1. Summary of analysis of variance for total yield (TY), marketable yield (MY), nitrogen concentration in the diagnostic leaf (NDL), percentage of bulbs in the Classes 2 (PB2), 3 (PB3) and 4 (PB4), percentage of non-marketable bulbs (PNMB), chlorophyll a (Cla), chlorophyll b (Clb), total chlorophyll (Cltotal), soluble solids (SS), titratable acidity (TA), SS/TA ratio and pungency (PUNG) of onion cultivars and nitrogen doses

\begin{tabular}{|c|c|c|c|c|c|c|c|c|}
\hline SV & DF & TY & MY & NDL & PB2 & PB3 & PB4 & PNMB \\
\hline & \multicolumn{8}{|c|}{ F-value } \\
\hline Blocks & 3 & $0.26^{\mathrm{ns}}$ & $0.22^{\text {ns }}$ & $1.19^{\text {ns }}$ & $0.01^{\mathrm{ns}}$ & $0.22^{\mathrm{ns}}$ & $0.52^{\text {ns }}$ & $0.07^{\mathrm{ns}}$ \\
\hline Cultivars (C) & 1 & 132.11 ** & 84.39 ** & $0.06^{\mathrm{ns}}$ & $94.65^{\star \star}$ & $11.62^{\star \star}$ & $101.89 * \star$ & $25.45^{\star *}$ \\
\hline $\mathrm{N}$ dose (D) & 6 & $20.71^{\star \star}$ & $19.19 * *$ & $4.67^{\star *}$ & $30.62^{\star *}$ & $6.37^{\star *}$ & $13.43^{\star *}$ & $3.98^{* *}$ \\
\hline$C \times D$ & 6 & $1.04^{\mathrm{ns}}$ & $0.78^{\text {ns }}$ & $0.36^{\mathrm{ns}}$ & $3.90^{* *}$ & $10.12^{\star \star}$ & $5.17^{\star *}$ & $1.54^{\mathrm{ns}}$ \\
\hline \multirow[t]{2}{*}{ CV (\%) } & & 10.82 & 11.93 & 14.27 & 25.96 & 10.82 & 45.26 & 43.61 \\
\hline & & Cla & Clb & Cltotal & SS & $\mathrm{TA}$ & SS/TA & PUNG \\
\hline Cultivars (C) & 1 & $0.00^{\mathrm{ns}}$ & $0.30^{\text {ns }}$ & $0.20^{\mathrm{ns}}$ & 326.51 ** & $46.06^{\star \star}$ & $5.99 *$ & 19.10 ** \\
\hline $\mathrm{N}$ dose (D) & 6 & $6.51^{\star *}$ & $6.89 * *$ & $8.80^{* *}$ & $1.87^{\mathrm{ns}}$ & $1.63^{\mathrm{ns}}$ & $1.05^{\mathrm{ns}}$ & $4.34^{* *}$ \\
\hline$C \times D$ & 6 & $1.77^{\mathrm{ns}}$ & $2.01^{\mathrm{ns}}$ & $1.95^{\mathrm{ns}}$ & $0.93^{\mathrm{ns}}$ & $3.10^{*}$ & $2.02^{\text {ns }}$ & $7.56^{\star \star}$ \\
\hline CV (\%) & & 15.68 & 16.55 & 13.50 & 5.69 & 10.62 & 12.05 & 14.27 \\
\hline
\end{tabular}

SV - Source of variation; DF - Degrees of freedom; ${ }^{* *}$ - Significant at $p \leq 0.01 ;^{*}$ - Significant at $p \leq 0.05$ and ns - Not significant at $p \leq 0.05$

*, ** - Significant at $\mathrm{p} \leq 0.05$ and $\mathrm{p} \leq 0.01$, respectively, by F test 
The percentage of bulbs in Class 2 (PB2) for the cultivar IPA 11 (23\%) was twice that observed for 'Rio das Antas' (11.4\%). In the production of Class 3 bulbs, the cultivar IPA 11 (68.2\%) also outperformed 'Rio das Antas' (61.8\%); however, in the production of Class 4 bulbs (PB4), the percentage obtained by the cultivar Rio das Antas (18.9\%) was four times higher than that for 'IPA 11' (4.6\%).

In the single-effect analysis of $\mathrm{N}$ doses for each cultivar on PB2, significant differences were found with negative effect on both cultivars, where the means of both 'IPA 11' and 'Rio das Antas' fitted to quadratic models (Figure 2A).

The $\mathrm{N}$ doses and PB2 observed in this study are consistent with those obtained by Resende \& Costa (2014), who found that the PB2 of the cultivar Alfa Tropical fitted to a quadratic model, with minimum value at the $\mathrm{N}$ dose of $179.9 \mathrm{~kg} \mathrm{ha}^{-1}$.

In the single-effect analysis of $\mathrm{N}$ doses for each cultivar on the percentage of bulbs in Class 3 (PB3), significant differences were found in both cultivars. However, only the data of the cultivar IPA 11 fitted to a mathematical model (Figure 2B).

Nitrogen fertilization caused a positive effect on the production of bulbs within this class in the cultivar IPA 11, reaching a maximum value of $78.5 \%$ at the $\mathrm{N}$ dose of $174.3 \mathrm{~kg} \mathrm{ha}^{-1}$. For Class 4 , significant differences were found only in the cultivar Rio das Antas, but there was no suitable adjustment to any regression model. For the cultivar Rio das Antas, the highest PB4 was obtained with the $\mathrm{N}$ dose of $180 \mathrm{~kg} \mathrm{ha}^{-1}$, whereas the lowest PB4 was observed without the application of this nutrient.

These results are in agreement with those reported by several authors who found increments in the production of bulbs in the Classes 3 and 4, due to the $\mathrm{N}$ fertilization in onion, with $\mathrm{N}$ doses ranging from 126 to $168 \mathrm{~kg} \mathrm{ha}^{-1}$ for Class

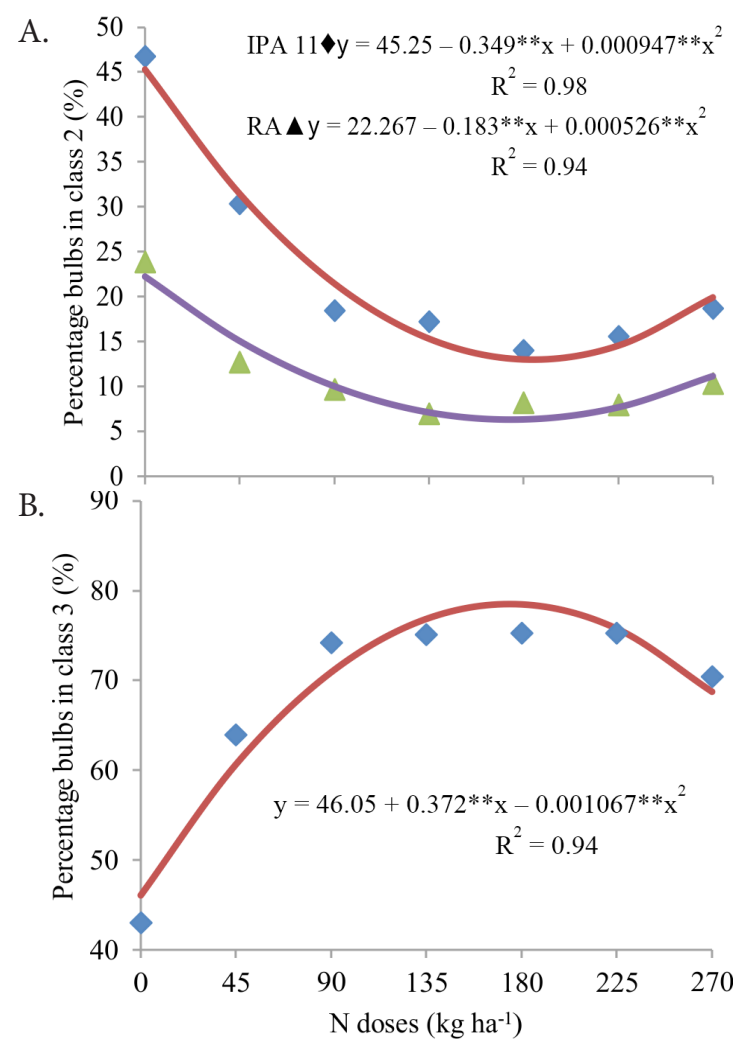

Figure 2. Percentage of bulbs in Class 2 in the cultivars IPA 11 and Rio das Antas - RA (A) and percentage of bulbs in Class 3 in the cultivar IPA 11 (B), as a function of $\mathrm{N}$ doses
3 (Cecílio Filho et al., 2010; Menezes Júnior \& Kurtz, 2016; Resende et al., 2016).

The percentage of non-marketable production, including bulbs with diameter $<35 \mathrm{~mm}$ and double bulbs, did not adjust to any regression model. The highest percentages (10.2 and 9.5\%, respectively, for 'IPA 11' and 'Rio das Antas') were obtained in the treatment without $\mathrm{N}$ application, whereas the lowest percentage were $2.2 \%$ for 'IPA 11' with $\mathrm{N}$ dose of $225 \mathrm{~kg} \mathrm{ha}^{-1}$ and 5.7\% for 'Rio das Antas' with maximum $\mathrm{N}$ dose.

The onion cultivars differed statistically with respect to soluble solids (SS) concentration, and 'IPA 11' (9.87 ${ }^{\circ}$ Brix) outperformed 'Rio das Antas' (7.49 $\left.{ }^{\circ} \mathrm{Brix}\right)$. The concentrations of soluble solids obtained in the present study are within the range found by Grangeiro et al. (2008), who evaluated 18 onion cultivars in Mossoró, RN, Brazil (6.7 to $11.63{ }^{\circ}$ Brix).

Different results were observed by Bolandnazar et al. (2012), Rodrigues et al. (2016) and Benti (2017), who identified reduction of SS with the increase in $\mathrm{N}$ doses.

The means of titratable acidity (TA) as a function of $\mathrm{N}$ doses for both cultivars did not adjust to any regression model. For the cultivar IPA 11, TA varied from 2.66 to 3.22 meq $\mathrm{H}_{3} \mathrm{O}^{+} 100 \mathrm{~g}^{-1}$ and for 'Rio das Antas', from 2.17 to 2.72 meq $\mathrm{H}_{3} \mathrm{O}^{+} 100 \mathrm{~g}^{-1}$.

TA was higher in the cultivar IPA $11\left(2.93\right.$ meq $\left.\mathrm{H}_{3} \mathrm{O}^{+} 100 \mathrm{~g}^{-1}\right)$ than in 'Rio das Antas' (2.41 meq $\mathrm{H}_{3} \mathrm{O}^{+} 100 \mathrm{~g}^{-1}$ ), although they were not significantly different at the $\mathrm{N}$ doses of 45,180 and $225 \mathrm{~kg} \mathrm{ha}^{-1}$.

The genetic factor (cultivar) is determinant for the chemical composition of onions (Kimura et al., 2014), but the environment and agronomic practices can be determinant for changes in the concentration of organic acids (Galdón et al., 2008).

Nitrogen fertilization did not influence the SS/TA ratio of onion cultivars. However, 'IPA 11' (3.49) stood out in comparison to 'Rio das Antas' (3.22).

The means of piruvic acid concentration (pungency PUNG) also did not fit to any regression model. The cultivar IPA 11 with mean value of $6.58 \mu \mathrm{mol} \mathrm{g}^{-1}$ showed higher PUNG compared to 'Rio das Antas' $\left(5.57 \mu \mathrm{mol} \mathrm{g}^{-1}\right)$, and in relation to the $\mathrm{N}$ doses, PUNG varied from 4.83 to $7.23 \mu \mathrm{mol} \mathrm{g}^{-1}$ and from 5.02 to $7.39 \mu \mathrm{mol} \mathrm{g} \mathrm{g}^{-1}$ for 'IPA 11' and 'Rio das Antas', respectively.

These results are in agreement with Bolandnazar et al. (2012) and Tekalign et al. (2012), who found positive influence of $\mathrm{N}$ fertilization on the PUNG concentration, respectively, in the cultivars Azar Shahr and Bombay Red.

The $\mathrm{N}$ dose of $108 \mathrm{~kg} \mathrm{ha}^{-1}$ produced the best economic indicators for 'IPA 11', with gross revenue (GR) of R $\$ 73,154.00$, net revenue (NR) of $R \$ 37,796.00$, return ratio (RR) of $R \$ 2.07$, profitability index (PI) of $51.67 \%$, break-even point (BEP) of $28,286.40 \mathrm{~kg} \mathrm{ha}^{-1}$ and safety margin (SM) of -0.52 . For 'Rio das Antas', these indicators were, respectively, $\mathrm{R} \$ 95,213.38$, $\mathrm{R} \$ 55,730.74, \mathrm{R} \$ 2.41,58.53 \%, 31,586.11 \mathrm{~kg} \mathrm{ha}^{-1}$ and -0.59 with the $\mathrm{N}$ dose of $82 \mathrm{~kg} \mathrm{ha}^{-1}$. These results agree with those verified by Hunger (2013), who evaluated the yield and performed an economic analysis of the onion cultivar Bola Precoce in Guarapuava, PR, Brazil, observing averages for RR of R $\$ 2.22$, SM of -0.55 and BEP of $29,341 \mathrm{~kg} \mathrm{ha}^{-1}$.

The dose which maximized the economic indicators of 'IPA 11 ' represented an increase in the total cost of only $2.8 \%$, but 
increasing the net revenue (NR) by $453 \%$. For 'Rio das Antas', the dose of $82 \mathrm{~kg} \mathrm{ha}^{-1}$ represented an increment of $1.9 \%$ in the total cost and an increase of $231 \%$ in NR.

The economic analysis demonstrates that onion production is a profitable business, with a comfortable safety margin, despite the wide variation of price every year.

\section{Conclusions}

1. The cultivar Rio das Antas was more productive than IPA 11.

2. The nitrogen dose which maximized the total and marketable yields was $92 \mathrm{~kg} \mathrm{ha}^{-1}$.

3. Nitrogen fertilization increased the percentage of Class 3 bulbs and reduced the percentage of non-marketable bulbs.

4. The $\mathrm{N}$ doses of 108 and $82 \mathrm{~kg} \mathrm{ha}^{-1}$ led to higher gross revenue, net revenue, return rate and profitability index for the cultivars IPA 11 and Rio das Antas, respectively.

\section{Literature Cited}

Allen, R. G.; Pereira, L. S.; Raes, D.; Smith, M. Crop evapotranspiration: Guidelines for computing crop water requirements. Rome: FAO, 1998. 300p. Irrigation and Drainage Paper, 56

Benti, G. Influence of nitrogen rate and varieties on storage periods of onion (Allium cepa L.) in Fedis district, Eastern Ethiopia. International Journal of Information Research and Review, v.4, p.4097-4105, 2017.

Bolandnazar, S.; Mollavali, M.; Tabatabaei, S. J. Influence of $\mathrm{NH}_{4} \mathrm{NO}_{3}$ and $\mathrm{K}_{2} \mathrm{SO}_{4}$ on qualitative characteristics of onion. Scientia Horticulturae, v.136, p.24-28, 2012. https://doi.org/10.1016/j. scienta.2011.12.022

Brasil. Ministério da Agricultura, Abastecimento e Reforma Agrária. Portaria n.529 de 18 ago. 1995. Brasília: Diário Oficial da República Federativa do Brasil, 1995. 5p.

Cecílio Filho, A. B.; Marcolini, M. W.; May, A.; Barbosa, J. C. Produtividade e classificação de bulbos de cebola em função da fertilização nitrogenada e potássica, em semeadura direta. Científica, v.38, p.14-22, 2010.

Factor, T. L.; Trani, P. E.; Breda Júnior, J. M.; Purquerio, L. F. V.; Grangeiro, L. C. Correção do solo e adubação. In: Nick, C.; Borém, A. (eds.). Cebola: Do plantio à colheita. Viçosa: UFV, 2018. Cap.4, p.58-77.

Ferreira, D. F. Sisvar: A computer statistical analysis system. Ciência e Agrotecnologia, v.35, p.1039-1042, 2011. https://doi.org/10.1590/ S1413-70542011000600001

Galdón, B. R.; Rodríguez, C. T.; Rodrigues, E. R.; Romero, C. D. Organic acid concentrations in onion cultivars (Allium cepa L.). Journal of Agricultural and Food Chemistry, v.56, p.6512-6519, 2008. https://doi.org/10.1021/jf800282h

Gao, J.; Na, M.; Zhou, J.; Wang, W.; Xiong, Z.; Mba, F. O.; Chen, N. Peroxidation damage and antioxidative capability of Ceratophyllum demersum under $\mathrm{NH}_{4}^{+}-\mathrm{N}$ stress. Journal of Freshwater Ecology, v.27, p.539-549, 2012. https://doi.org/10.10 80/02705060.2012.674007
Grangeiro, L. C.; Souza, J. O.; Aroucha, E. M. M.; Nunes, G. H. S.; Santos, G. M. Características qualitativas de genótipos de cebola. Revista Ciência e Agrotecnologia, v.32, p.1087-1091, 2008. https:// doi.org/10.1590/S1413-70542008000400008

Hunger, H. Produtividade e análise econômica da cultura da cebola sob diferentes densidades de plantio e níveis de adubação. Guarapuava: UNICENTRO, 2013. 52p. Dissertação Mestrado

IBGE - Instituto Brasileiro de Geografia e Estatística. Produção agrícola municipal (PAM). 2017. Available on: <http://www.sidra. ibge.gov.br/>. Accessed on: Jan. 2018.

Isla, R.; Guillén, M.; Salmerón, M. Nitrogen availability effects on gas exchange measurements in field-grown maize (Zea mays L.) under irrigated Mediterranean conditions. Spanish Journal of Agricultural Research, v.14, p.1-9, 2016. https://doi.org/10.5424/ sjar/2016144-9109

Kimura, Y.; Okazaki, K.; Yanagida, D.; Muro, T. Cultivar and regional diferences in the metabolite composition of onion (Allium сера). Scientia Horticulturae, v.168, p.1-8, 2014. https://doi. org/10.1016/j.scienta.2014.01.019

Melo, C. O.; Moretti, C. L.; Machado, C. M. M.; Mattos, L. M.; Muniz, L. B. Alterações físicas e químicas em cebolas armazenadas sob refrigeração. Ciência Rural, v.42, p.2078-2084, 2012. https://doi. org/10.1590/S0103-84782012001100027

Menezes Júnior, F. O.; Kurtz, C. Produtividade da cebola fertirrigada sob diferentes doses de nitrogênio e densidades populacionais. Horticultura Brasileira, v.34, p.571-579, 2016. https://doi. org/10.1590/s0102-053620160418

Resende, G. M.; Costa, N. D. Dose econômica de nitrogênio na produtividade e armazenamento de cultivares de cebola. Horticultura Brasileira, v.32, p.357-362, 2014. https://doi. org/10.1590/S0102-05362014000300019

Resende, G. M.; Costa, N. D.; Yuri, J. E. Doses de nitrogênio na produtividade e classificação de bulbos de cultivares de cebola. Revista Brasileira de Agricultura Irrigada, v.10, p.605-613, 2016. https://doi.org/10.7127/rbai.v10n300373

Rodrigues, G. S. O.; Grangeiro, L. C.; Negreiros, M. Z.; Silva, A. C.; Novo Júnior, J. Qualidade de cebola em função de doses de nitrogênio e épocas de plantio. Revista Caatinga, v.28, p.239-247, 2016. https://doi.org/10.1590/1983-21252015v28n327rc

Rodrigues, G. S. O.; Grangeiro, L. C.; Lima, J. S. S. de; Chaves, A. P.; Bezerra Neto, F.; Medeiros, J. F.; Novo Júnior, J. Onion yield as a function of nitrogen dose. Revista Ciências Agrarias, v.41, p.4651, 2018. https://doi.org/10.19084/RCA17154

Scopel, W.; Barbosa, J. Z.; Vieira, M. L. Extração de pigmentos foliares em plantas de canola. Unoesc \& Ciência - ACET, v.2, p.87-94, 2011.

Tekalign, T.; Abdissa, Y.; Pant, L. M. Growth, bulb yield and quality of onion (Allium cepa L.) as influenced by nitrogen and phosphorus fertilization on Vertissol. II: Bulb quality and storability. African Journal of Agricultural Research, v.7, p.5980-5985, 2012. https:// doi.org/10.5897/AJAR10.1025

Trani, P. E.; Breda Júnior, J. M.; Factor, T. L. Calagem e adubação da cebola (Allium cepa L.). Campinas: Instituto Agronômico de Campinas, 2014. 35p.

UFV - Universidade Federal de Viçosa. SAEG - Sistema de análises estatísticas e genética. Viçosa: UFV, 1997. 59p. 